as one who is to be served. 'The Swedish co-operators, who had much to contribute to the general theme of improving on our present methods of distribution, as also some of the other foreign visitors, were given little opportunity or encouragement to take an active part in the discussions.

Similar remarks could be made about the other sections.

During the meeting "The American Society for the Advancement of Management" held a dinner for those attending the Congress, at which various New Deal administrators were invited to speak. This was the only occasion during the week at which the New Deal was mentioned, other than in derogatory terms. From the point of view of the visitors from overseas, this was the most instructive meeting, for here alone was it possible to learn about things which they did not understand, and to hear things which had been heard many times before.

\title{
Research and Development in Glass Technology
}

\author{
New Laboratories at St. Helens
}

$\mathrm{T}$ HE new researeh laboratories of Messrs. Pilkington Brothers, Ltd., at St. Helens, opened by Sir William Bragg on October 5, represent a yet further stage in the scientific development of glass technology in which such striking progress has been made during the post-War years. At the luncheon before the opening ceremony, Lord Cozens-Hardy, chairman of the company, reviewed its progress ; the firm has carried out glass manufacture at St. Helens for more than a century, the first works chemist having been appointed in 1844 and the analytical laboratory dating from 1869 . He referred to the high level of glass making which had been attained by chemical and technical skill in the early years of the century. Not only was it known what types of ingredients and proportions were necessary to obtain high-quality glass, but also very considerable strides had been made in manufacturing refractories to stand up well to high-temperature conditions without being unduly attacked by the molten glass. Since the Great War, however, the manufacture of glass has largely been mechanized, necessitating very close control of the compositions and the temperature at which glass is melted and worked. Out of the experimental investigations necessitated by this position there has grown a technical development department.

Towards the end of 1936, the directors of Messrs. Pilkington Brothers decided to supplement this work by forming a research laboratory, closely associated with which was to be a general analytical laboratory for control of the Company's products. The new research department is intended to function in the more academic field of science and will, it is expected, frequently be responsible for fundamental work on first principles. The problems with which the new laboratories will be confronted fall into seven categories, covering the melting of glass, the study of refractories, the processing of glass, uses of glass, the properties of glass, methods of testing glass, and miscellaneous matters such as the production of mirrors to withstand rigorous weathering and temperature conditions, etc. Lord Cozens-Hardy referred to further advances in glass manufacture which are approaching completion, by which a ribbon of glass flowing out of a tank is passed successively through the annealing process and through a grinding and polishing machine which treats both sides simultaneously, the whole machine being more than 1,000 feet long. Its use, it is believed, will once more completely revolutionize the manufacture of plate glass.

Before cutting a glass silk ribbon across the doorway of the new laboratory, Sir William Bragg referred to the way in which in recent years the use of $\mathrm{X}$-ray methods has elucidated the ultimate structure of glass with some approach to completion. The remarkable net-like structure thus revealed has laid the founda. tion for a wholly new attempt to relate the physical and other properties of glass with its chemical constitution. This fuller understanding of the constitution of glass has led to further control over manufacturing methods.

The new laboratories have been built to the design of Mr. Herbert J. Rowse, who also designed the United Kingdom Government Pavilion at the Glasgow Exhibition. Together with the equipment, the cost of

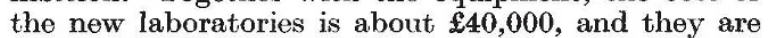
designed to house the director of research, Dr. $H$. Moore, and a staff of forty-seven, including fifteen to twenty university graduates and about twenty-five qualified technical assistants. The laboratories are designed essentially to meet individual requirements, and a novel feature is the use of glass bricks for the internal corridor walls. Most of the physical laboratories are devoted to special instruments or special testing processes, and they include an X-ray laboratory with a fully automatic X-ray apparatus for the identification of crystals and the determination of the viscosity of glass. Other laboratories are specially equipped for thermal expansion measurements, the determination of refractive index and hardness, the measurement of the bending of loaded glass beams, flatness testing and optical work. Among the equipment of the latter is a photometer head integrating sphere for measuring the transmission of light through opaque glass and a Babinet strain viewer. An annexe to the laboratory is devoted to hightemperature work on refractories, glass melting and toughening. Among the apparatus exhibited was a stirring test designed by a member of the staff for comparing the merits of different materials for the construction of tank surfaces. In this apparatus five fingers of these various materials, fixed into a flat circular plate, are rotated vertically in a bath of molten glass at $1,500^{\circ}$.

The main block of the research laboratories includes a large analytical laboratory and laboratories for general chemical research and organic research. In 
addition, the building includes a library, the furniture for which was made in Messrs. Pilkington Brothers own carpentry and cabinet-making shops. The library already contains a nucleus of about 2,000 books, including a number of the earliest records of the firm dating from 1869. A number of striking examples of coloured glasses and fluorescent glass were shown in the laboratories. Both the exhibits and the equipment of the laboratories fully justified Sir William Bragg's remarks as to the national importance of the inauguration of this new research institution.

\section{Fifth International Congress for Applied Mechanics}

\begin{abstract}
$\mathrm{T}$ HE Fourth International Congress for Applied Mechanics was held at Cambridge, England, in 1934, and the Fifth very appropriately met at Cambridge, Massachusetts, on September 12-16. The Congress was attended by more than four hundred members as the guests of Harvard University and the Massachusetts Institute of Technology. More delightful hosts could not have been desired by the members who shared in the meetings and in the entertainments arranged by the local committee consisting of H. M. Westergaard, J. P. Den Hartog, J. C. Hunsaker, L. S. Marks and H. Peters.

The Congress was opened by Prof. K. T. Compton, president of the M.I.T., acting as president of the Congress. The work of the Congress was accomplished by means of technical sessions at which communications from members were read, by general lectures, and by a symposium on turbulence. The field of applied mechanies was divided into the following general heads : (I) Structures, elasticity, plasticity, fatigue, strength theory, crystal structure. (II) Hydro and aerodynamics, gas-dynamics, hydraulics, meteorology, water waves, heat transfer. (III) Dynamics of solids, vibration and sound, friction and lubrication, wear and seizure. Simultaneous sessions of the three sections were held. Abstracts of the papers presented were printed in English in the September issue of the Journal of Applied Mechanics, a copy of which was given to each member. Communications were received from the following workers from the British Empire : S. Brodetsky, L. P. Coombes, J. N. Goodier, A. A. Hall, C. E. Inglis, G. J. Klein, L. M. MilneThomson, E. F. Relf, F. G. Richardson, D. M. Smith, A. V. Stephens, J. L. Synge, and G. I. Taylor, who gave a general lecture on turbulence. The meetings were held at the M.I.T. for the first four days, and on the last day at Harvard University.
\end{abstract}

On Monday, September 12, members were able to be present at the dedication at the M.I.T. of the Wright Brothers Wind Tunnel, among the speakers at the opening ceremony being G. Brewer, of the Royal Aeronautical Society. The tunnel is a closed welded cylindrical steel circuit, with a 2,000 h.p. electric-motor and a variable pitch propeller, in which the air can be compressed to four atmospheres giving a Reynolds' number of $6,500,000$, or exhausted to one quarter of an atmosphere, when a velocity of 400 miles per hour is expected to be attained. The working section of this remarkable tunnel is an ellipse, ten feet by seven and a half feet.

Apart from attending lectures and hearing papors read, one of the great advantages of an international Congress is the opportunity of scientific workers from different countries meeting personally and exchanging ideas in a quite informal fashion. This opportunity was amply afforded by the receptions and conversaziones which were organized for each evening and contributed in no small measure to the success of the meetings. The largest social undertaking, apart from the final dinner, was the excursion on Thursday, September 15, to Middlesex School, the route passing through Lexington and Concord, places famous in American history. At the School a picnic supper was served, an address on Galileo's "Discorsi" was given by Dean S. H. Hollister, of Cornell University, and the proceedings were thereafter enlivened by a bonfire and a male chorus of Boston Negroes.

Following the Congress, members were invited to visit the National Bureau of Standards at Washington, D.C., and the aeronautical laboratory at Langley Field, Virginia. Many members availed themselves of this opportunity of seeing important scientific work in progress, and some very pleasant parts of the United States.

\section{New Laboratories of the Metropolitan Water Board}

WW Laboratories of the Metropolitan Water
Board were opened by the Minister of Health,
the Right Hon. Walter Elliot, M.P., on October 17
in the presence of a distinguished company. They
are situated at New River Head, Rosebery Avenue,
adjacent to the Boord's head offices, and replace
laboratories in Nottingham Place, which have been
in use since 1905.
The Metropolis Water Act of 1871 provided for
the appointment of a 'water examiner' by the Board
of Trade, and in early days the water supplied by the London water companies was subjected to daily examination by Sir William Crookes and Profs. James Dewar and Percy Frankland. Under the Metropolitan Water Act, 1902, by which the several existing water companies were consolidated into one undertaking under the newly constituted Metropolitan Water Board, the Board was similarly placed under an obligation to conduct chemical and bacteriological examinations of its water.

The Board in 1905 appointed the late Sir Alexander Houston to be "Director of Water Examinations"; 